\title{
Chapter 12 \\ Theory, the Market and the State: Agricultural Reforms in Post Socialist Uzbekistan Between Economic Incentives and Institutional Obstacles
}

\author{
Bernd Hansjürgens
}

\begin{abstract}
Water pricing is seen as an important element in efficient water resource management. By providing information about water resource scarcity, water prices can make explicit the value of water and can set adequate incentives for water users to use water more sustainably. However, designing efficient water resource pricing schemes is dependent on many prerequisites that are hard to fulfil. In this chapter, we contrast the prerequisites of water pricing with real-world contexts in the Fergana Valley. We show that many prerequisites for water pricing are not met in this area, so that water pricing reforms are unable to perform the functions usually associated with water prices. Nevertheless, it is possible to articulate a number of steps toward a reform of the agricultural sector which may at least point the way towards a more sustainable use of water resources.
\end{abstract}

Keywords Water scarcity $\bullet$ Fergana Valley $\bullet$ Water resources $\bullet$ Efficient water pricing $\bullet$ Water services $\bullet$ Interdependence of orders $\bullet$ Design elements $\bullet$ Institutional obstacles • Agricultural sector • Paths for reform • Water rights • Water users associations

\subsection{Introduction: The Need to Price Water Resources in the Fergana Valley}

Water scarcity refers to a situation in which water demand exceeds water supply. While many people assume that water scarcity is a problem of absolute scarcity (i.e. water not being available at all), the economic approach addresses water scarcity as a relative problem, meaning that the needs of those who wish to use water for certain

\footnotetext{
B. Hansjürgens $(\bowtie)$

Department of Economics, Helmholtz Centre for Environmental

Research - UFZ, Permoserstraße 13, 04318 Leipzig, Germany

e-mail: bernd.hansjuergens@ufz.de
} 
purposes (irrigation, drinking water, industrial production, ecological functions and services, etc.) cannot be met with available water resources. As with most resources on Earth, water scarcity is a far-reaching and ubiquitous problem.

The Fergana Valley in Uzbekistan is characterised by severe water scarcity. Although the annual amount of water in the region is regarded as sufficient - due to high precipitation rates in the upstream river areas - there are seasonal fluctuations: There is too much water available in the wintertime, leading to flooding in the Valley, whereas particularly during the summer months, the needs of water users often cannot be met. As a consequence, water resources have to be managed, through allocation to users according to certain decision-making rules or specific allocation mechanisms (e.g. quotas).

In the literature, several factors are mentioned as being the cause of water scarcity in the Fergana Valley (Giese and Sehring 2007; Dukhovny and de Schutter 2011). While these causes are diverse in nature, they can nevertheless be grouped into two major categories:

- One set of sources refers to the transboundary character of water resources in Central Asia (e.g. Libert et al. 2008; Dukhovny and de Schutter 2011, p. 280; Eschment 2011; Wegerich et al. 2012). After the breakdown of the Soviet Union, the then-Soviet provinces became independent states. During the Soviet era, the interests of upstream users and downstream users were (more or less) balanced via state planning: The downstream water users Uzbekistan, Turkmenistan and Kazakhstan had to deliver energy in the winter to the upstream users Kyrgyzstan and Tajikistan, while the upstream users had to provide sufficient water to the downstream users in the summertime. This situation changed completely in the early 1990s. The upstream users increasingly used the water resources for hydropower production in winter to safeguard their energy. The result was (and still is) that too much water was delivered to downstream users in winter, while water for downstream users (mainly for the irrigation of cotton plants) was insufficient in the summer. Thus, the Central Asia water crisis is generally regarded as being the result of a lack of (international) cooperation and coordination (Dukhovny and de Schutter 2011, p. 281).

- A second group of authors refers to the inefficiency of water resource management in the Fergana Valley (e.g. Abdullaev et al. 2007; Schlüter et al. 2010, p. 621; Abdullaev and Atabaeva 2012; Kenjabaev and Frede 2015, in this volume). These authors focus on the argument that despite the existence of large infrastructure facilities for water irrigation in the Fergana Valley (i.e. the Fergana Canal and a comprehensive canal system with far-reaching grids), there are high water losses due to the outmoded infrastructure of the canal system and an inefficient use of water (Abdullaev et al. 2007; Libert et al. 2008, p. 18; Dukhovny et al. 2009). Water losses in the Fergana Valley are estimated to be in the order of nearly $50 \%$ of total water availability (Giese and Sehring 2007, p. 12). A decline in financial resources is seen as a key reason for this. While in the past the water sector was among the strongest sectors in Uzbekistan in terms of financial state flows (Abdullaev and Atabaeva 2012, p. 106), the amount of money devoted to 
sustaining the technical systems and the management of the irrigation system has decreased in both absolute and relative terms (ibid, p. 10). Today there are clear signs of problems in sustaining the infrastructure all over Uzbekistan.

Although the problems of water management are multicausal and mutually interconnected, in this contribution, we focus on the second line of argument, namely, the situation within the Fergana Valley. We want to focus on those factors of water management that can be influenced independently by the Uzbekistan government. Many proposals have been put forward with the aim of improving the water management system in the Fergana Valley. The most important policy recommendations and measures include, inter alia, the following elements (Dukhovny and de Schutter 2011, p. 319):

- Management information systems

- A training and qualification programme

- IWRM

- Development of a monitoring system

- Evaluating water demand and adjusting irrigation

- Introduction of water prices

Although there is no doubt that the decline of the water sector in the Fergana Valley can only be overcome by a comprehensive approach covering (at least) several of the above-mentioned elements, in the following we refer to just one aspect that is part of nearly every proposal: the role of water resources pricing. We want to shed some light on the potential of pricing mechanisms and on how these mechanisms can serve as incentives for more efficient resource use in the agricultural sector. At the same time, we want to address the institutional prerequisites for introducing water prices and to highlight the obstacles that prevent water prices from performing their functions. By explicitly focusing on the design elements and prerequisites of water pricing mechanisms on the one hand and on the institutional obstacles involved in the case of the Fergana Valley on the other, we want to illustrate how difficult it is to apply theory-based recommendations to the specific context-dependent situations found in real-world societies, with their historical path dependencies and institutional restrictions. By focusing on these aspects, we see our contribution as taking a similar line of reasoning as other chapters in this volume that point to the need to combine technical, economic and societal perspectives in order to develop well-functioning major water engineering projects (MWEPs).

The following section will outline some "economics of water pricing". In elaborating the preconditions for introducing an effective and efficient water pricing scheme, we want to elucidate the notion that any successful instrument has to be based on "good" design. We also want to raise awareness that designing such instruments is an "art" that can rarely be achieved in real-world policy processes, even in Western countries with their - compared to Central Asian states - much more effective institutions and governance structures. In the following section, we will focus on the institutional settings that shape the conditions in the agricultural sector in Uzbekistan. Our use of the term "institutional settings" refers to the formal and 
informal rules, norms, customs and habits in Uzbekistan's agricultural sector that shape farmers' behaviour. We will show that efficient pricing (in the sense that economic incentives are set for water users) cannot easily be achieved under such conditions. This leads to the conclusion that proposals for institutional reforms in relation to major water infrastructure projects cannot be based on a "nirvana approach" but have instead to be examined carefully with respect to the specific political, administrative and cultural conditions at hand. Nevertheless, in the final section we point out some possible pathways for step-by-step reforms that at least point in the direction of water-related reforms.

\subsection{Some Economics of Water Pricing}

Setting prices for environmental goods such as water resources serves several functions (Rogers et al. 2002; Young 2005):

1. Financing function: By introducing water levies (be it a fee, charge, tax, special contribution, or some other form of public financing), public revenues are generated that can be used for investments in the water sector. So one goal of introducing water prices is to generate financial resources in order to finance water-related infrastructures.

2. Information function: It is assumed that water prices, if properly calculated, reveal the "true value" of water resources. Demonstrating the true value of water by pricing water resources may serve to reflect the value a society accords to water resources. This is a prerequisite if water users are to obtain the necessary information about water scarcity and to carry the "full costs" of water when making decisions about water resource use.

3. Incentives function: By providing price signals that have to be integrated into decision-making, water users are incentivised to calculate the cost of water (including private and social costs) as part of their decisions regarding their use of water resources. Thus, private and public decisions will be changed, and water saving can be achieved if water users are confronted with the full costs of water. Water pricing can thus be seen as a management principle that leads to more sustainable water use. For many water experts, then, setting adequate incentives is a fundamental prerequisite for achieving efficiency in water resource use.

Interestingly (but not surprisingly), current discussions about water pricing in the Fergana Valley focus solely on the financing function. There are several reasons for this:

- First, since the building of the Fergana Canal and the Fergana Valley irrigation grid system in the late 1930s, water management has been considered mainly as a technical enterprise: Building, sustaining and managing the technical infrastructure have primarily been seen as the main task of water management engineering. All technical, managerial and financial resources have been devoted to building and 
maintaining the technical systems. Water problems have predominantly been perceived as problems of infrastructure supply and only to a lesser degree (if at all) as problems of demand management. "Water management strategies are still strongly "Soviet" in approach, regarded by state actors as purely "technical", because other dimensions - economic, social and political - are "fixed" through the state regulation" (Abdullaev and Mollinga 2010, p. 85).

- Second, as a consequence, the reasons for the decline in infrastructure were (and still are) associated mainly with a lack of financial resources in the water sector (in addition to the lack of international cooperation). This has been aggravated by the fact that the influence of the water management authorities has decreased since the end of the Soviet era.

- Third, the organisations and public authorities responsible for water management have not had any experience in the use of water pricing mechanisms as a means of steering users' behaviour in a certain direction. They emerged and developed within a system of state-driven supply management and control (Eschment 2011, p. 20) and are therefore not familiar with the functioning of market-based environmental instruments such as prices. Not surprisingly, the other two functions of water pricing - providing information and setting incentives - have been widely ignored in decision-making.

- Fourth and finally, the design of adequate water prices becomes more difficult the more the state actors' interests are oriented towards protecting the agricultural sector. As will be shown in detail below, the planting of cotton as a major state crop is still given top priority in Uzbekistan. There is little to no political will to make the agricultural sector pay for the water services it receives.

From an economic perspective, however, the information and incentive functions are crucial elements of water pricing policy. The idea behind economic thinking is that users of water resources should bear the full costs of their resource use. This leads to two problems that have to be solved (Hansjürgens 1997; Gawel 2001):

1. What are the full costs of water and its services?

2. Who should bear the full costs of water services?

\subsubsection{What Are the Full Costs of Water and Its Services?}

What costs should form the basis for pricing water resources? Or, more precisely, what cost elements should be included? Figure 12.1 illustrates possible answers (Rogers et al. 2002; Young 2005). From an economic perspective, the cost of water includes all the resources that are required to deliver a unit of water to the end user. These costs comprise not only the operation and maintenance $(\mathrm{O} \& \mathrm{M})$ costs of daily running water-related supply systems (e.g. purchased raw water, electricity for pumping, labour, repair materials, input costs for managing and operating storage, distribution and treatment plants) but also the costs that have to be spent to build up and consolidate the necessary infrastructures (depreciation charges, interest 
Fig. 12.1 Costs of water - full cost of a single use (Adapted from Rogers et al. 2002, p. 7)

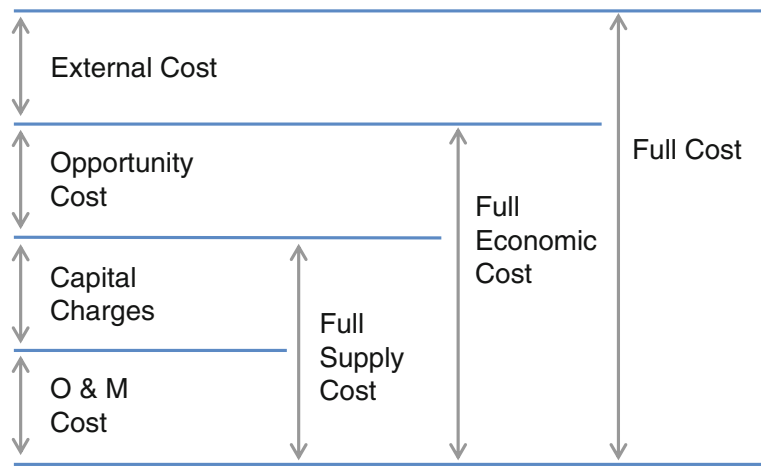

charges). Thus, the capital costs of financing water-related infrastructures have to be included. In addition, there are two further cost categories that have to be taken into account from an economic perspective. "Opportunity costs" refer to the fact that consuming water for one purpose deprives other users of water (if water is used, say, for agricultural irrigation, it is no longer available to private households or ecosystems). Using the money for water services means that the foregone net benefits from alternative uses is a cost. Opportunity costs are zero if there are no alternative uses, i.e. if there is no shortage of water. Finally, water use may be associated with external costs, i.e. costs imposed on other actors. These may be the costs associated with polluting or extracting water, i.e. environmental costs. If upstream users use water for energy production, this may lead to flooding; from the perspective of the upstream water user, this is an "external" cost, but it is nevertheless a cost borne by society. Similarly, the costs of irrigating land may lead to changing groundwater tables or to water losses for downstream users; this is a cost for uninvolved thirdparty groups or society as a whole. These costs are "external" from the perspective of the agricultural users.

Of course, calculating these costs is not an easy task. Even in industrialised countries with the highest technical standards and properly functioning governance structures, it is extremely difficult. The reason is that environmental costs in particular are hard to define, as it is almost impossible to calculate external effects (Baumol and Oates 1988). The point here is that from an economic perspective, all these costs should nevertheless - at least in principle - be included in water pricing in order to fulfil the prerequisite that water prices fully reflect their information and incentive function (Rogers et al. 2002, p. 9).

Following these definitions of costs of water resource use, the pricing mechanism can follow three perspectives (Hansjürgens 1997):

1. A "refinancing perspective" suggests that only past and present costs of water supply systems are financed via water prices; this includes investment costs, variable $\mathrm{O} \& \mathrm{M}$ costs and foreign capital costs.

2. A "company perspective", aimed at preserving the value of the infrastructure, additionally includes calculatory depreciation (based on current costs) and cal- 
culatory capital costs (for using internal financial resources for investment purposes).

3. The "economic perspective" of water pricing includes not only private costs, as is the case in the refinancing and company perspective, but also so-called social costs, which refers to additionally including environmental and resource costs. The latter refers to societally assessed external effects where the calculation of these social costs is a major (albeit largely unresolved) challenge.

\subsubsection{Who Should Bear the Full Costs of Water Services?}

Even if the task of defining the (full) costs has been tackled successfully, the second question is how (according to which rules) costs should be distributed among water users. In order to steer human behaviour, the costs of water have to be transmitted directly to the water users following their use of the resource. The reason is that, in the economic model, it should be the water user who decides upon strategies and means to change his or her behaviour. Two arguments can be put forward for this, based on fairness and allocation, respectively:

1. The water user is the person who benefits directly from using water resources. Accordingly, following the polluter pays principle, this person should be the addressee of pricing in order to bear the costs of resource use. It is generally considered fair that the user of a resource should pay for that use.

2. Water users are normally those who know best how to change their water-related behaviour, because they have the most comprehensive knowledge of ways to avoid water use (Hansjürgens 2001): They can avoid water use by reducing consumption, they can use water more effectively, or they can reduce pollutants so that water quality is safeguarded. Thus, the polluter pays principle is not only a principle of fairness but also a principle of allocative efficiency.

Having explained the two basic steps of defining water prices - defining the full costs of water and distributing these costs among water users in a way that confronts users with the true costs of the water resources they use - we now turn to the design issues of water pricing. Our aim in highlighting these issues is to make two points clear: (1) Water pricing is an "art" that involves resolving some very difficult methodological and design-specific "technical" problems. (2) Water pricing is a political challenge that involves mitigating the influence of those who lose power in the process of setting price incentives.

- Who pays the water price?

The water price should be paid by the entity (individual, private household, company, farmer, etc.) that uses the water resources. But who is the user of the resources? Answering this question is more difficult than it seems at first sight. Is it the water company that draws water from groundwater tables? Or is it the 
water users association (WUA) that receives the water from the water company and allocates it to the farmer? Or is it the farmer himself or herself?

Different water pricing schemes can be developed depending on how the water user is defined. If it is only the water provisioning company that has to pay water prices, a water saving incentive is only set (if at all) for the provisioning company. The question arises whether and how the water company will pass on the price to the end users. Will this happen explicitly by levying fees or charges or implicitly by raising the water price? How can it be ensured that the end users are confronted with the true costs of their resource use? Are the end users those entities that can best reduce water resource use or avoid the pollution and degradation of water resources? In addition, many types of water user can be subject to pricing: the user of potable water, the discharger of wastewater, the owner of a house (if the house is rented, the owner is not necessarily the same as the user), the individual farmer, etc.

- What is the price for?

If the user of water resources is identified and addressed by the water price, a second question is "what does the payer pay for?" Is it water consumption or wastewater discharge (or both)? Or is it the grid and delivery system that is chosen as a basis for pricing water? If the farmer is chosen as the addressee of water pricing, is the price related to his or her real consumption or is it related to the farm size? Is it a fixed price derived from a certain formula, or is the price set according to "actual" (real) use (requiring the monitoring of use along with measuring devices)?

- How much does the payer have to pay?

The payment is usually referred to as the price of water (in the narrow sense). Bearing in mind the comments above regarding the definition of "full costs" of water, however, several issues have to be resolved: Should the water price be based on average costs or on marginal costs? An average cost-based water price would lead to identical costs for all water users, while the marginal cost-based water price would burden the users according to their specific (marginal) resource use (the amount of water they use). From an economic perspective, marginal cost pricing is superior to average cost pricing because end users are directly confronted with their resource use. However, for marginal cost pricing, measuring and monitoring issues have to be resolved. For both types of pricing, it is necessary to ask which cost components are included: full costs including external costs or full supply costs or $\mathrm{O} \& \mathrm{M}$ costs? Do the costs refer to short-term costs or long-term costs (including new investments)? If current costs (instead of historical costs of investment) are chosen, what is the adequate discount rate?

- What is the tariff?

The water tariff determines how the price is imposed on different consumers. Here, several options are possible: The tariff could be based on a fixed rate, i.e. irrespective of consumption (this is called a flat rate), or on a variable rate where the price per unit of assessment base is linear, progressive or degressive. A block tariff can be chosen, or the price can be single part (with only a fixed or a variable component) or two part (with a fixed and a variable component). It could be 
uniform (the same for all users) or else differentiated (by user groups). All these features can also be found in different variants, e.g. different tariffs can be combined.

These design elements, which can be taken from textbooks on water management or taxation (public finance), have been presented here to demonstrate that water pricing is a rather complicated issue, where a broad range of "technical" design questions have to be addressed. Apart from these design questions, which are difficult to resolve (due to a lack of institutional and managerial capacity and expertise), there is another factor that might impede the introduction of water prices: If water prices are introduced, there will be individuals or groups in society that have to face higher cost burdens. There are losers compared to the status quo where no water prices exist. In many cases, these "losers" are powerful interest groups that undertake huge political efforts to prevent the introduction of water prices or - if their introduction as such cannot be avoided - seek to influence the design of the water prices in a way that ensures they themselves are not burdened. The agricultural sector can be seen as such a pressure group in most countries, regardless of the societal system (decentralised market-based economy or more centralised planned economy).

Having explained the key elements of "the economics of water pricing", we now turn to the situation in the Fergana Valley. We want to illustrate that the conditions in the Valley do not provide the necessary basis for introducing any type of efficient water pricing.

\subsection{Political and Institutional Obstacles}

\subsubsection{Protection of the Agricultural Sector}

"Cotton has been a major crop in Uzbekistan at least from the time of the Russian empire" (Abdullaev et al. 2007, p. 112). During Soviet times, Uzbekistan became one of the main producers and the second largest exporter of cotton in the world. Central Asia became the "cotton basket" of the Soviet Union (see also Weinthal 2006; Abdullaev and Atabaeva 2012, p. 107). The factors that made this development possible were, first, the growing proportion of land under irrigation, achieved by expanding the Fergana Valley irrigation system and securing sufficient amounts of water during summer periods, ${ }^{1}$ and, second, the state order of the Soviet Union that prescribed the planting of nearly $100 \%$ cotton in the area (Abdullaev et al. 2007, p. 113; Abdullaev and Atabaeva 2012, p. 107).

After the breakdown of the Soviet Union in 1991, the former provinces became independent states. Although the existing rules governing water allocation between

\footnotetext{
1 "The hydraulic mission has started its journey in Central Asia" (Abdullaev and Atabaeva 2012, p. 104). "Hydraulic mission" means here that in Soviet times, "water professionals started to develop their way of working, translating and adapting many unrealistic, idealistic ideas of communist party into 'real-life' situations" (ibid, p. 107). At the same time "Central Asia became part of 'heroic' history of irrigation engineering" (ibid, p. 105).
} 
the Central Asian states were safeguarded by means of the 1992 "Agreement on Cooperation in Joint Management, Use and Protection of Interstate Sources of Water Resources" (Libert et al. 2008, p. 11), the water situation changed dramatically because the Central Asian states acted independently, following their own interests (Libert et al. 2008; Sehring 2009). The upstream users did not allocate sufficient water to the downstream users in the summertime, while the energy provision from downstream to upstream users in the wintertime was no longer guaranteed. The two principles contained in International Water Law that there should be "equitable and reasonable utilisation of transboundary water resources [and that] the obligation of one State should not cause significant harm to another State through its use of shared water resources" were violated (Libert et al. 2008, p. 12).

However, this did not mean that Uzbekistan's agricultural policy "really" changed (Abdullaev and Atabaeva 2012, p. 105). Its focus was and still is on cotton production. The state response to the new political situation was to seek independence in the provisioning of food by import substitution. This had become a necessity since the import of wheat from other Soviet states ceased in the early 1990s. Thus, Uzbekistan's politicians were forced to focus their primary policy objective on safeguarding people's nutrition. As a consequence, wheat became the second important crop that was imposed by the state. In addition to structural changes, which focused on more individual freedom for farmers and reduced farm sizes (Abdullaev et al. 2007), "the Uzbekistan government's decision to promote wheat self-sufficiency is largely responsible for the recent decline in cotton production" (Weinthal 2006, p. 20).

Nevertheless, cotton production is still a key element of Uzbekistan's agricultural policy (see Fig. 12.2). A large proportion of Uzbekistan's export revenues derive from cotton production, while the sector provides a high percentage of employment (Weinthal 2006, p. 19; Abdullaev et al. 2007, p. 113). As the export of cotton is organised predominantly by state authorities, state revenues are highly dependent on this source. For this reason, the regulations stipulating which crops farmers are to plant have not really changed. Instead of imposing a single "cash crop", as in the Soviet era, farmers are now required to plant two cash crops. Today, nearly $85 \%$ of state production is reserved for these two "cash crops". ${ }^{2}$ Nevertheless, the production of cotton has decreased over time (see Fig. 12.2).

With respect to the recommendation to introduce water prices, the developments described here have an important implication: In Uzbekistan, there has hardly been any political will to introduce (efficient) water prices in the agricultural sector. Burdening the agricultural sector with additional state-imposed prices was - and still is - a taboo. Political decision makers have an interest in protecting the agricultural sector from the imposition of water-related prices. This has been fully embedded in the tradition of Uzbekistan's political decision makers, where all past decisions were oriented towards prioritising - and not burdening - the agricultural

\footnotetext{
${ }^{2}$ One should be aware that in Uzbekistan "cash crop" refers to certain crops that are exported and therefore generate revenues; thus, primarily, cotton can be described as a "cash crop" in this sense. Wheat is primarily required for meeting the population's food needs - and not for acquiring "cash".
} 


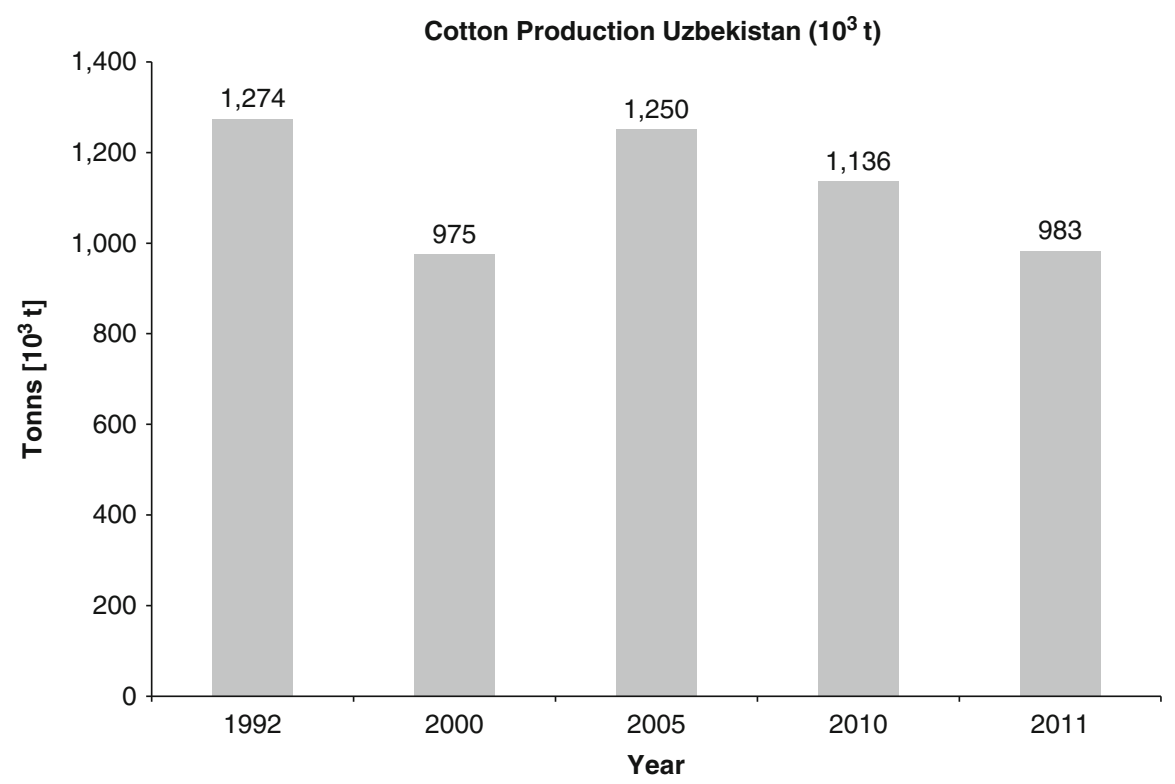

Fig. 12.2 Cotton production in Uzbekistan $\left(10^{3} \mathrm{t}\right)$ (Source: Modified from Shamukhitdinova and Adelt 2013, p. 7). It should be noted that the official statistics might underestimate the amount of cotton produced, as some of the cotton produced might not be sold to "official state authorities" but to neighbouring countries through informal ("black") markets

sector. Instead of paying for water, farmers receive significant subsidies for water irrigation. "The obtainment of free inputs is an implicit side-payment from the state to the farmers that allows them to use water for other purposes [...] [F]armers have few incentives to conserve water" (Weinthal 2006, p. 22). Although water scarcity has increased dramatically in the region over the last 25 years, this tendency to favour agriculture has not been overcome to this day. ${ }^{3}$

A further element that aggravates these tendencies even further can be seen in the fact that water management issues in Central Asia have been focused on supplyside management measures to date. The history of water management in Russian times and later in the Soviet era of Central Asia is part of the "heroic history of irrigation engineering" (Abdullaev and Atabaeva 2012, p. 105). All water-related problems were considered as technical problems to be solved with the assistance of large-scale technical solutions. Thus, the notion of steering demand by changing

\footnotetext{
${ }^{3}$ It should be noted here that this is similar to many other countries where a felt need to protect the agricultural sector can be observed. See, for example, the reference to Israel in this volume where the authors state that the concern to protect the agricultural sector is "deeply rooted in the Zionist movement" (Bismuth et al. 2015, in this volume, pp. 253-275). Similarly, in Germany, the water extraction charge (Wasserpfennig or Wasserentnahmeentgelt), which is levied in some German states, must be paid by water users - and not (!) by the agricultural sector. Instead, the revenues are used to compensate farmers for income losses due to reduced use of nitrogen and fertilisers in water protection areas. The polluter pays principle is thus reversed.
} 
water users' consumption patterns does not even seem to exist. In fact, when such ideas were presented by the author at a conference on water-related problems in Central Asia in May 2014, for most conference participants they lay outside the scope of their perceptions of water management practices for the region.

\subsubsection{No Freedom for Individual Choice}

A second obstacle to efficient water pricing can be seen in the fact that the addressees of water prices do not have a chance to respond economically. While on paper there have been attempts to transform the former Soviet Union central planning system into a market economy, many changes in the economic and political system in Uzbekistan have remained gradual. The economic and political system in Uzbekistan was (and still is) shaped by the modes and characteristics of central planning regimes. Abdullaev and Atabaeva (2012) therefore speak of a "slow transformation" process. "But the voluntary change of a state apparatus in the case of Central Asian countries only happened with minor changes that remain to be surface changes" (Abdullaev and Atabaeva 2012, p. 105). "All states of the [Central Asian] region have returned in different forms back to control of agriculture in different forms" (ibid, p. 108). Moss and Hamidov (2015, in this volume) speak of a "gradual approach to market reform".

From an economic perspective, the decisive point is that private property in the agricultural sector is not fully realised; farmers do not have full powers of decisionmaking regarding their inputs and outputs. To understand this issue, farmers' decisions have to be seen in their specific institutional contexts: Farmers are obligated to plant the two "cash crops", cotton and wheat, on their land. They have to buy all the necessary inputs (seed, fertilisers, etc.) on credit. They are even told what to plant, when to plant and where to plant. In addition, they cannot decide by themselves when and how to irrigate their fields. They are also told when to harvest the crops (Weinthal 2006, p. 20). There is hardly any autonomy with respect to the resources they input or the quantity and quality of their output. The farmers receive a fixed price for their harvest which allows them to pay back their loans. However, the price is far lower than the world price for cotton so that private profits cannot be made. "Because the government has always granted [the farmers] debt relief, they have little incentive to become more efficient by reducing their inputs and managing their level of debt like individual private farmers. [...] As a result, [they] still operate without any hard-budget constraints" (Weinthal 2006, p. 21).

Certainly, there have been some changes in the system since independence. The growing number of smaller farms (compared to the huge kolkhozes) has led to a decrease of the previously centralised decision-making procedures in collective farming that were dominated by the heads of agricultural units. Instead, decollectivisation has led former members of the collective farms as well as citizens 
with no agricultural experience to become individual farmers (Weinthal 2006, pp. 19-22; Abdullaev and Atabaeva 2012, p. 109). These farmers have gained partial access to production inputs, but water access has still been dominated by the former collective decision makers and/or the newly emerging water users associations (see below). The individual farmers apply different means (power, money, influence, good connections, etc.) to gain access to water to irrigate their crops (for a case study in the Fergana Valley, see Abdullaev and Mollinga 2010, p. 93). Thus, in times of increasing scarcity, water allocation became subject to bargaining and "good relationships". It was not the water price, however, that controlled the distribution of water among users but rather other factors that determined the outcome of these socio-economic processes. "The influence and control of the water management processes have been considerably reduced due to individualisation of the agricultural processes. The water professional's role has been replaced by set of water control strategies of newly emerging water users: large, small, subsistence farmers, fisheries and constructors, etc., who started to compete for water for their purposes. The water management became more socio-technical process not only technical" (Abdullaev and Atabaeva 2012, p. 109).

Choices about land use - which crops to plant on given areas of land - are defined by state quotas. "Even if farmers fulfil their cotton production quota, they can still be penalised if the area they plant with cotton is less than the requirement" (Abdullaev et al. 2007, p. 116). Farmers' decisions are therefore mainly characterised by restricted property rights or the absence of property rights for resource use. The term "property rights" refers to the rights to use a resource or a good independently, i.e. to buy, rent or sell a resource or a good (Alchian 1965; Eggertsson 1990). Defined property rights are a prerequisite for using goods and resources efficiently. They are the basis for independent and efficient decisions in a market economy. It is only when individual decision makers face the full consequences of their behaviour that they will take all the consequences of their decision into account. Furthermore and this is crucial in the present context - property rights are also a prerequisite for the proper functioning of pricing mechanisms.

Market prices only make sense if there are clearly defined property rights. Prices deliver information that forms the basis for individuals' choices. They set incentives to react economically to changing supply and demand conditions and thus to changing conditions of scarcity. Following this line of argument, water prices set by politicians make sense only if there is a clear definition of such property rights and if property rights are allocated to individual decision makers. Farmers can only follow price incentives if they have the freedom to choose among several alternatives. Therefore, if water prices are to incentivise resource users, this can only be accomplished if the resource users have freedom of choice. Clearly defined property rights where decisions about goods and resources are connected with private property are indispensable for the use of water prices as a policy instrument.

These considerations can be traced back to the early proponents of the idea of a market economy such as Walter Eucken (1890-1950). Eucken stated that systemic 
changes in a societal system (from centralised planning to a market economy) can only be achieved if all its elements (market economy for the economic system, democratic decision-making for the political system, separation of powers, legal provisions for protecting individuals' rights) are changed simultaneously. There is an "interdependence of orders" (Eucken 1952/1990). If only certain elements of system transformation are taken into account, transformations will fail.

There is a second closely related argument that highlights the relevance of individual responsibilities: the polluter pays principle. This principle states that the polluter or user of a resource has to pay for the costs associated with resource use. In general, this principle is primarily seen as a distributional principle, contributing to the fairness of environmental burden sharing between resource users. It should be noted, however, that it also follows an underlying efficiency principle: The resource user knows best how to use a resource efficiently (Hansjürgens 2001). This efficiency argument also emphasises that water pricing schemes should address the user of resources - seen here as the individual who knows best how to change his or her behaviour.

As long as farmers' property rights in the Fergana Valley are not clearly defined, it is likely that water prices will not work properly. Water prices may succeed in generating public revenues that may in turn help to finance infrastructure investments. However, they will fail as an information and steering mechanism. Thus, the general theoretical claim that water prices lead to more efficient water resource use may fail unless real-world obstacles in the agricultural sector are taken into account.

\subsubsection{Lack of Clearly Defined Water Rights and Unclear Role of Water Users Associations}

Closely related to the aforementioned argument regarding property rights (which referred to farmers' discretionary powers to use their land) is the role of property rights with regard to water - water rights. Setting price incentives also requires property rights for water uses. However, farmers in the Fergana Valley lack not only property rights over the use of inputs and outputs, they particularly lack property rights over water resources (an input in agricultural production); water management is subordinate to agricultural needs (Abdullaev and Mollinga 2010, p. 93).

Historically, the allocation of water was placed in the hands of water users associations (WUAs). WUAs not only own and maintain pumps and clean the smaller irrigation canals, they also introduce their own rules for water distribution and monitor water allocations (Abdullaev et al. 2010). These organisations were implemented in the early 2000s (Moss and Hamidov 2015, in this volume) as a reaction to the water allocation problems in Uzbekistan at that time. The increasing individualism of the agricultural sector after decentralisation, involving a transition from the former Soviet type of large-scale farming to a more diverse structure with smaller fields and a considerably higher number of farmers, led to a mismatch 
between agricultural and water-related institutional structures. The latter still relied on the rules for allocating water to the cash crop-producing state farms, while the need to allocate water between different uses (cash crops of cotton and wheat, but also privately planted crops like rice and vegetables) and different levels of decisionmaking increased. Abdullaev and Mollinga (2010, pp. 93-98) provide an institutional analysis of water-related decision-making, pointing to the fact that, in addition to the newly created water users associations, agricultural quotas for cotton and wheat production, ancient rules about "water turns", neighbourhood relationships and clans also had a major impact on de facto decision-making. As a result, water users associations are not seen primarily as an organisation that represents the needs of water users but rather as another water administration body imposed on farmers in a top-down manner (Abdullaev et al. 2010, p. 1035). As one reaction, in addition to water users associations, water user groups emerged, as "true" representatives of farmers and water users (Abdullaev and Mollinga 2010), where the "farmers have taken water management into their own hands" (Moss and Hamidov 2015, in this volume, pp. 149-167).

It is not necessary to go into the details of institutional change here. Rather, the key argument here is that water users associations, as the decisive organisational units for solving water irrigation issues, were (and still are) relatively weak so that there has been no opportunity to introduce pricing at this level. As the water users associations are not financed by the state, they depend heavily on the fees and charges they impose on farmers. However, these fees and charges rarely reflect the situation of water scarcity, as they are usually based on farm size and the type of crop (Moss and Hamidov 2015, in this volume, pp. 149-167). Consequently, the incentives for using water more effectively are relatively weak. The payment is seen more as a membership contribution (rather like a tax) than as a fee or charge that is imposed in exchange for services received. There is no connection between the water use and the revenues raised, as it is not water itself but the area of land that is subject to taxation; the tax base and the tariff also lack incentives for efficient water use. Needless to say that the prerequisites for monitoring - which requires metering not only at the level of the main canals but also at the level of secondary and tertiary canals and grids - are not met (Weinthal 2006, p. 19). Also, compliance is not achieved as many members of WUAs just do not pay the charges imposed on them. The result is, as Kenjabaev (2014, p. 27) notes, "neither WUAs nor farmers and other water users have an incentive to know the applied and delivered amount of water as no price is set for water in Uzbekistan."

It is not surprising that water allocation in many cases does not reflect the rules of the WUAs, but is embedded in historical decision-making, which means that former elites and power constellations are more important than written rules. Against this background, the pricing of water resources has no chance of being introduced and implemented. Recalling once more Walter Eucken's (1952/1990) observation that there is an "interdependence of orders", pricing as one element of dealing with water scarcity makes little sense if other issues such as well-defined 
property rights in the agricultural and the water sector, effective governance structures and a clear division of responsibilities are not resolved.

\subsection{Concluding Remarks}

Water pricing is considered by many economists and water experts to be a key element in water management. It is seen as a crucial step towards coping with the adverse effects of increasing water scarcity. This paper has contrasted the theoretical idea of water pricing with the practical obstacles evident in Uzbekistan. Uzbekistan is a post-Soviet era country where the process of transformation into a market economy with decentralised decision-making has been rather slow. Although the water-related irrigation system in the area is among the oldest and most extensive in the world, there is almost no integrative management of water resources that incorporates the possibility of incentivising water users.

It has become clear that water-related technologies are closely connected with socio-economic developments. Using water for agricultural purposes is a practice deeply rooted in Uzbek society so that irrigation is given high priority over other water uses. These institutional (cultural, legal and economic) roots constitute a powerful obstacle to introducing water prices in the area. Path and context dependencies that have emerged over decades cannot be overcome in a short period of time.

It can thus be concluded that in this geographical area, the challenge of increasing water scarcity cannot (yet) be met by introducing water prices. Without a comprehensive reform of property rights (including land and water-related property rights), water prices will not work properly. These findings contradict not only economists' recommendations that are based on a theoretical "nirvana approach" but also the opinion of water experts and practitioners in Central Asia that focus exclusively on financial factors when calling for water prices as a key element in solving the water scarcity problems in the area.

What, then, are the alternatives? Indeed, are there any? The answer to these questions would go beyond the scope of this paper and so cannot be given here. But there are certain steps that could be taken which potentially point in the right direction. One could be to reduce the amount of cash crops to be grown, thus giving farmers more freedom to plant crops in accordance with their own interests. Another step would be to strengthen the role of the WUA in the sense that they might actually become the kind of organisations they already are on paper, namely, ones that represent farmers' interests. It remains an open question whether Uzbekistan will go in such a direction.

Open Access This chapter is distributed under the terms of the Creative Commons Attribution Noncommercial License, which permits any noncommercial use, distribution, and reproduction in any medium, provided the original author(s) and source are credited. 


\section{References}

Abdullaev I, Atabaeva S (2012) Water sector in Central Asia: slow transformation and potential for cooperation. Int J Sustain Soc 4:103-112. doi:10.1504/IJSSOC.2012.044668

Abdullaev I, Mollinga PP (2010) The socio-technical aspects of water management: emerging trends at grass roots level in Uzbekistan. Water 2:85-100. doi:10.3390/w2010085

Abdullaev I, Giordano M, Rasulov A (2007) Cotton in Uzbekistan: water and welfare. In: Kandiyoti D (ed) The cotton sector in Central Asia economic policy and development challenges. The School of Oriental and African Studies. University of London, London, pp 112-128

Abdullaev I, Kazbekov J, Manthritilake H et al (2010) Water user groups in Central Asia: emerging form of collective action in irrigation water management. Water Resour Manag 24:1029-1043. doi:10.1007/s11269-009-9484-4

Alchian A (1965) Some economics of property rights. Il Politico 30:816-829

Baumol WJ, Oates WE (1988) The theory of environmental policy, 2nd edn. Cambridge University Press, Cambridge

Bismuth C, Hansjürgens B, Yaari I (2015) Technologies, incentives and cost recovery: is there an Israeli role model? In: Huettl RF, Bens O, Bismuth C, Hoechstetter S (eds) Society - water technology: a critical appraisal of major water engineering projects. Springer, Dordrecht, pp 253-275

Dukhovny VA, de Schutter J (2011) Water in Central Asia - past, present, future. Taylor \& Francis, London

Dukhovny V, Sokolov V, Manthrithilake H (2009) Integrated water resources management: putting good theory into real practice. Central Asian Experience. Scientific Information Center of the Interstate Commission for Water Coordination (SIC ICWC), Tashkent

Eggertsson T (1990) Economic behavior and institutions. Cambridge University Press, Cambridge

Eschment B (2011) Wasserverteilung in Zentralasien. Ein unlösbares Problem? Friedrich Ebert Stiftung, Berlin

Eucken W (1952/1990) Grundsätze der Wirtschaftspolitik, 6th edn. Mohr, Tübingen

Gawel E (2001) Effizienz im Umweltrecht. Grundsatzfragen wirtschaftlicher Umweltnutzung aus rechts-, wirtschafts- und sozialwissenschaftlicher Sicht. Nomos, Baden-Baden

Giese E, Sehring J (2007) Regionalexpertise - Destabilisierungs- und Konfliktpotenzial prognostizierter Umweltveränderungen in der Region Zentralasien bis 2020/2050. Wissenschaftlicher Beirat der Bundesregierung Globale Umweltveränderungen (WBGU), Berlin

Hansjürgens B (1997) Gebührenkalkulation auf Basis volkswirtschaftlicher Kosten? Anwendungsprobleme und Lösungsmöglichkeite. Archiv für Kommunalwissenschaften 36:233-252

Hansjürgens B (2001) Das Verursacherprinzip als Effizienzregel. In: Gawel E (ed) Effizienz im Umweltrecht. Grundsatzfragen wirtschaftlicher Umweltnutzung aus rechts-, wirtschafts- und sozialwissenschaftlicher Sicht. Nomos, Baden-Baden, pp 381-396

Kenjabaev SM (2014) Ecohydrology in a changing environment. Dissertation, Justus-LiebigUniversität Gießen

Kenjabaev SM, Frede H-G (2015) Irrigation infrastructure in Fergana today: ecological implications - economic necessities. In: Huettl RF, Bens O, Bismuth C, Hoechstetter S (eds) Society water - technology: a critical appraisal of major water engineering projects. Springer, Dordrecht, pp 129-148

Libert B, Orolbaev E, Steklov Y (2008) Water and energy crisis in Central Asia. China Eurasia Forum Quart 6:9-20

Moss T, Hamidov A (2015) Where water meets agriculture: the ambivalent role of the water users associations (WUAs). In: Huettl RF, Bens O, Bismuth C, Hoechstetter S (eds) Society - water technology: a critical appraisal of major water engineering projects. Springer, Dordrecht, pp 149-167

Rogers P, de Silva R, Bhatia R (2002) Water is an economic good: how to use prices to promote equity, efficiency, and sustainability. Water Policy 4:1-17. doi:10.1016/S1366-7017(02)00004-1 
Schlüter M, Hirsch D, Pahl-Wostl C (2010) Coping with change: responses of the Uzbek water management regime to socio-economic transition and global change. Environ Sci Pol 13:620636. doi:10.1016/j.envsci.2010.09.001

Sehring J (2009) The politics of water institutional reform in neo-patrimonial states: a comparative analysis of Kyrgyzstan and Tajikistan. VS Verlag für Sozialwissenschaften, Wiesbaden

ShamukhitdinovaL,AdeltS (2013)DieWiederbelebung zentralasiatischertextilerHandwerkstechniken im Prozess der Nationsbildung in Usbekistan. Zentralasien-Analysen 72:2-8

Wegerich K, Kazbekov J, Mukhamedova N et al (2012) Is it possible to shift to hydrological boundaries? The Ferghana Valley meshed system. Int J Water Res Dev 28:545-564. doi:10.10 80/07900627.2012.684316

Weinthal E (2006) Water conflict and cooperation in Central Asia. Prepared as background paper for the UN human development report 2006. http://hdr.undp.org/sites/default/files/weinthal_ erika.pdf. Accessed 9 Apr 2015

Young R (2005) Determining the economic value of water: concepts and methods. RFF Press, Washington, DC 